\title{
Trajetórias escolares, corpo negro e cabelo crespo: reprodução de estereótipos ou ressignificação cultural?
}

\author{
Nilma Lino Gomes
}

Universidade Federal de Minas Gerais, Faculdade de Educação

Muito se tem discutido sobre a importância da escola como instituição formadora não só de saberes escolares como, também, sociais e culturais. Tendo isso em vista, alguns estudiosos do campo da educação e da cultura têm destacado o peso da cultura escolar no processo de construção das identidades sociais, enfatizando a escola como mais um espaço presente na construção do complexo processo de humanização (Arroyo, 2000; Bruner, 2001). Por essa perspectiva, a instituição escolar é vista como um espaço em que aprendemos e compartilhamos não só conteúdos e saberes escolares, mas também valores, crenças, hábitos e preconceitos raciais, de gênero, de classe e de idade.

Aos poucos, os educadores e as educadoras vêm interessando-se cada vez mais pelos estudos que articulam educação, cultura e relações raciais. Temas como a representação do negro nos livros didáticos, o silêncio sobre a questão racial na escola, a educação de mulheres negras, relações raciais e educação infantil, negros e currículo, entre outros, começam a ser incorporados na produção teórica educacional. Porém, apesar desses avanços, ainda nos falta equacionar alguns aspectos e compreender as muitas nuances que envolvem a questão racial na escola, destacando os mitos, as representações e os valores, em suma, as formas simbólicas por meio das quais homens e mulheres, crianças, jovens e adultos negros constroem a sua identidade dentro e fora do ambiente escolar.

Lamentavelmente, nem sempre damos a essas dimensões simbólicas a devida atenção dentro do ambiente escolar e, quando o fazemos, nem sempre as consideramos dignas de investigação científica e merecedoras de um trato pedagógico. Dessa forma, um dos caminhos para a ampliação do estudo da questão racial no campo da educação, na tentativa de compreender a sua relação com o universo simbólico, pode ser a construção de um olhar mais alargado sobre a educação como processo de humanização, que inclua e incorpore os processos educativos não-escolares. Poderemos, então, captar as impressões, representações e opiniões dos sujeitos negros sobre a escola, elegendo, com base nesses dados, temáticas que nem sempre são destacadas em nosso campo de atuação e que mereceriam um estudo mais profundo. A relação do negro com o corpo e o cabelo é uma dessas temáticas. 
Mas como captar as impressões e representações do negro sobre o próprio corpo, articulando-as com as experiências escolares e não escolares? Esta não é uma tarefa fácil, porém não é impossível. Um dos caminhos para a sua realização poderá ser o desenvolvimento de uma escuta atenta, por parte dos educadores e das educadoras, ao que os negros e as negras têm a dizer sobre as suas vivências corpóreas dentro e fora dos muros da escola. Ao desenvolvermos a pesquisa Corpo e cabelo como ícones de construção da beleza e da identidade negra nos salões étnicos de Belo Horizonte (Gomes, 2002), para a realização do doutorado em antropologia social, ${ }^{1}$ várias depoentes, ao reportarem-se ao corpo, relembraram momentos significativos da sua história de vida, dando um destaque especial à trajetória escolar. Para essas pessoas, na sua maioria mulheres negras jovens e adultas, na faixa dos 20 aos 60 anos, a experiência com o corpo negro e o cabelo crespo não se reduz ao espaço da família, das amizades, da militância ou dos relacionamentos afetivos. A trajetória escolar aparece em todos os depoimentos como um importante momento no processo de construção da identidade negra e, lamentavelmente, reforçando estereótipos e representações negativas sobre esse segmento étnico/racial e o seu padrão estético. O corpo surge, en-

${ }^{1}$ Os espaços pesquisados nos quais o cabelo crespo é a principal matéria-prima são quatro salões étnicos da cidade de Belo Horizonte. Deles emergem concepções semelhantes, diferentes e complementares sobre a beleza negra e a condição do negro na sociedade brasileira. Dois deles localizam-se no "centro da cidade" e os outros dois em bairros bem próximos dessa região.

Os sujeitos da pesquisa são 28 mulheres e homens negros. Destes, 17 são mulheres e 11 são homens. São jovens e adultos, da faixa etária dos 20 aos 60 anos. Dentre estes destacam-se as cabeleireiras e os cabeleireiros dos quais cinco são mulheres e quatro são homens. Do total de cabeleireiras/os, seis são proprietárias/os e as/os outras/os são funcionárias/os de confiança. A parte mais intensa da etnografia, com um acompanhamento diário de cada salão, iniciou-se em agosto/setembro de 1999 e terminou em janeiro de 2001. O trabalho estendeu-se até 2002, porém, nesse período, a ida ao campo tornou-se mais esparsa. tão, nesse contexto, como suporte da identidade negra, e o cabelo crespo como um forte ícone identitário. Será que ao pensarmos a relação entre currículo, multiculturalismo e relações raciais e de gênero, levamos em conta a radicalidade dessas questões?

$\mathrm{Na}$ instituição escolar, assim como na sociedade, nós comunicamos-nos por meio do corpo. Um corpo que é construído biologicamente e simbolicamente na cultura e na história. A antropologia mostra-nos que as singularidades culturais são dadas não somente pelas dimensões invisíveis das relações humanas. São dadas, também, pelas posturas, pelas predisposições, pelos humores e pela manipulação de diferentes partes do corpo. Por isso, a articulação entre educação e antropologia poderá trazer-nos novas luzes sobre o estudo das relações raciais e apontar-nos novos temas por meio dos quais a trama na qual a trajetória escolar é tecida desenvolve-se de maneira lenta e complexa.

O corpo fala a respeito do nosso estar no mundo, pois a nossa localização na sociedade dá-se pela sua mediação no espaço e no tempo. Estamos diante de uma realidade dupla e dialética: ao mesmo tempo que é natural, o corpo é também simbólico. Ele pode ser a "referência revolucionária da universalidade do homem no contraponto crítico e contestador à coisificação da pessoa e à exploração do homem pelo homem na mediação das coisas" (Martins, 1999, p. 54).

As diferentes crenças e sentimentos, que constituem o fundamento da vida social, são aplicadas ao corpo. Temos, então, no corpo, a junção e a sobreposição do mundo das representações ao da natureza e da materialidade. Ambos coexistem de maneira simultânea e separada. Por isso, não podemos apagar do corpo os comportamentos e motivações orgânicas que se fazem presentes em todos os seres humanos, em qualquer tempo e lugar. A fome, o sono, a fadiga do corpo, o sexo são motivações biológicas às quais a cultura atribui uma significação especial e diferente. É a cultura que, à sua maneira, inibirá ou exaltará esses impulsos, selecionando dentre todos quais serão os inibidos, quais serão os exaltados e ainda quais serão os considerados sem importância e, portanto, 
tenderão a permanecer desconhecidos. Assim, a cultura dita normas em relação ao corpo, às quais o indivíduo tenderá a conformar-se à custa de castigos e recompensas, até o ponto de estes padrões de comportamento apresentarem-se tão naturais quanto $o$ desenvolvimento dos seres vivos ou o pôr-do-sol (Rodrigues, 1986, p. 45).

Quando pensamos nos africanos escravizados e trazidos para o Brasil, sempre vem à nossa mente o processo de coisificação do escravo materializado nas relações sociais daquele momento histórico. Esse processo se objetivava não só na condição escrava, mas na forma como os senhores se relacionavam com o corpo dos escravos e como os tratavam: os castigos corporais, os açoites, as marcas a ferro, a mutilação do corpo, os abusos sexuais são alguns exemplos desse tratamento. Mesmo diante de tal situação, em que a liberdade oficial estava condicionada à carta de alforria, os escravos e as escravas desenvolveram as mais diversas formas de rebelião, de resistência e de busca da liberdade. Naquele contexto, a manipulação do corpo, as danças, os cultos, os penteados, as tranças, a capoeira, o uso de ervas medicinais para cura de doenças e cicatrização das feridas deixadas pelos açoites foram maneiras específicas e libertadoras de trabalhar o corpo. Por esses costumes é possível percebermos o corpo como uma referência revolucionária da universalidade do homem, apontada por Martins (1999, p. 54). Se o corpo fala a respeito do nosso estar no mundo, a relação histórica do escravo com o corpo expressa muito mais do que a idéia de submissão, insistentemente pregada pela sociedade da época e que ecoa até hoje em nossos ouvidos. Será que a escola tem dado uma outra leitura a essa relação? Ou as crianças negras e brancas, quando estudam a questão racial, ainda participam da representação do corpo negro apenas como um corpo açoitado e acorrentado? Será que hoje, em pleno terceiro milênio, os livros didáticos e as discussões sobre a história do negro no Brasil realizadas pela escola destacam que o corpo negro, desde a época da escravidão, sempre foi um corpo contestador?
Durante séculos de escravidão, a perversidade do regime escravista materializou-se na forma como o corpo negro era visto e tratado. A diferença impressa nesse mesmo corpo pela cor da pele e pelos demais sinais diacríticos serviu como mais um argumento para justificar a colonização e encobrir intencionalidades econômicas e políticas. Foi a comparação dos sinais do corpo negro (como o nariz, a boca, a cor da pele e o tipo de cabelo) com os do branco europeu e colonizador que, naquele contexto, serviu de argumento para a formulação de um padrão de beleza e de fealdade que nos persegue até os dias atuais. Será que esse padrão está presente na escola? A existência de um padrão de beleza que prima pela "brancura", numa sociedade miscigenada como a nossa, afeta ou não a nossa vida nas diferentes instituições sociais em que vivemos? Essas representações estão presentes na escola? Como?

A relação do homem com o corpo é pautada por um imperioso processo de alteração. Manipular, adornar, alterar, pintar, escarificar, tatuar, cortar são ações que fazem parte da dinâmica cultural e dos diferentes rituais de toda e qualquer sociedade. À medida que o corpo vai sendo tocado e alterado, ele é submetido a um processo de humanização e desumanização. A experiência corporal é sempre modificada pela cultura, segundo padrões culturalmente estabelecidos e relacionados à busca de afirmação de uma identidade grupal específica. Segundo Queiroz e Otta (2000), "marcas deixadas por escarificações, perfurações, tatuagens e mesmo algumas mutilações (circuncisão, extração de clitóris etc.) são sinais de pertinência, de identidade social, ao mesmo tempo que assinalam a condição tida por autenticamente humana daqueles que a exibem" (p. 21).

O corpo evidencia diferentes padrões estéticos e percepções de mundo. Pinturas corporais, penteados, maquiagem adquirem, dentro de grupos culturais específicos, sentidos distintos para quem os adota e significados diferenciados de uma cultura para outra. E é justamente o olhar sobre o corpo negro na escola que nos leva a considerar como professores/as e alunos/as negros e brancos lidam com dois elementos 
construídos culturalmente na sociedade brasileira como definidores do pertencimento étnico/racial dos sujeitos: a cor da pele e o cabelo.

Destacaremos, neste trabalho, de maneira especial, o peso da trajetória escolar na conformação da identidade negra, dos sentimentos e das impressões sobre o cabelo crespo na vida de mulheres negras jovens e adultas que freqüentam salões de beleza étnicos. Parto do pressuposto de que a maneira como a escola, assim como a nossa sociedade, vêem o negro e a negra e emitem opiniões sobre o seu corpo, o seu cabelo e sua estética deixa marcas profundas na vida desses sujeitos. Muitas vezes, só quando se distanciam da escola ou quando se deparam com outros espaços sociais em que a questão racial é tratada de maneira positiva é que esses sujeitos conseguem falar sobre essas experiências e emitir opiniões sobre temas tão delicados que tocam a sua subjetividade.

O discurso pedagógico, ao privilegiar a questão racial, não gira somente em torno de conceitos, disciplinas e saberes escolares. Fala sobre o negro na sua totalidade, refere-se ao seu pertencimento étnico, à sua condição socioeconômica, à sua cultura, ao seu grupo geracional, aos valores de gênero etc. Tudo isso se dá de maneira consciente e inconsciente. Muitas vezes, é por intermédio desse discurso que estereótipos e preconceitos sobre o corpo negro são reproduzidos. Será que eles são superados?

O discurso pedagógico proferido sobre o negro, mesmo sem referir-se explicitamente ao corpo, aborda e expressa impressões e representações sobre esse corpo. O cabelo tem sido um dos principais símbolos utilizados nesse processo, pois desde a escravidão tem sido usado como um dos elementos definidores do lugar do sujeito dentro do sistema de classificação racial brasileiro.

Essa situação não se restringe ao discurso. Ela impregna as práticas pedagógicas, as vivências escolares e socioculturais dos sujeitos negros e brancos. É um processo complexo, tenso e conflituoso, e pode possibilitar tanto a construção de experiências de discriminação racial quanto de superação do racismo.

\section{Cabelo e trajetória de vida}

As experiências do negro em relação ao cabelo começam muito cedo. Mas engana-se quem pensa que tal processo inicia-se com o uso de produtos químicos ou com o alisamento do cabelo com pente ou ferro quente. As meninas negras, durante a infância, são submetidas a verdadeiros rituais de manipulação do cabelo, realizados pela mãe, tia, irmã mais velha ou pelo adulto mais próximo. As tranças são as primeiras técnicas utilizadas. Porém, nem sempre elas são eleitas pela então criança negra - hoje, uma mulher adulta - como o penteado preferido da infância.

Talvez esse seja um dos motivos pelos quais algumas dessas mulheres prefiram adotar alisamentos e alongamentos na atualidade. A sensação de ter o cabelo constantemente desembaraçado e de não precisar sofrer as pressões do pente ou os puxões para destrançar o cabelo foram comentários constantes, durante as entrevistas, acompanhados de expressões de alívio; quando o assunto era o uso das tranças durante a infância, sempre ouvíamos uma infinidade de reclamações:

- Eu odiava! Minha mãe fazia quatro tranças e juntava de duas a duas no alto da minha cabeça! ${ }^{2}$ (N.U., 26 anos, cabeleireira étnica)

- Puxava tanto o meu cabelo para ele ficar ajeitadinho que até esticava os meus olhos. Parecia uma japonesa preta! (J., 23 anos, cabeleireira étnica)

- Não, nem sempre fui de bem com o meu cabelo, não... desde criança, não. Porque era aquele problema de puxar, trançar, aquela coisa toda. Não tinha alisamento, então, na hora de mamãe pentear o cabelo, era um drama. Aí, depois, já mocinha, é que eu fui me cuidando, aquela coisa toda é que mudou. Mas de criança, não, eu chorava, não gostava de pentear o cabelo porque doía, puxava daqui, puxava dali, mas depois... depois ficou bom. E está até agora... (S.A, 51, anos auxiliar de escritório)

${ }^{2} \mathrm{Na}$ transcrição das entrevistas e de trechos do diário de campo, todos os grifos são meus. 
- Minha mãe, pra pentear o cabelo, ela quase matava a gente. Fazia aquelas trancinhas. A gente... eu ficava com a cabeça toda doendo. Hoje em dia não tem isso mais, não é? Veja minha filha, olha o cabelo dela e olha o meu na época dela, não tem nem comparação. Hoje em dia está bom para o lado da pessoa negra, porque antigamente... nossa! Quando não era aquele ferro quente, pente quente que passavam no cabelo da gente, passavam aquele negócio. Ficava até bonito, mas depois... caia uma poeirinha, nossa, ficava um horror. Isso foi até eu atingir a minha idade de adulta. Não tinha opção. Tinha que usar isso mesmo. Agora é que apareceu cabelo de tudo quanto é jeito. (M., 25 anos, dona de casa)

O uso de tranças é uma técnica corporal que acompanha a história do negro desde a África. Porém, os significados de tal técnica foram alterados no tempo e no espaço. Nas sociedades ocidentais contemporâneas, algumas famílias negras, ao arrumarem o cabelo das crianças, sobretudo das mulheres, fazemno na tentativa de romper com os estereótipos do negro descabelado e sujo. Outras fazem-no simplesmente como uma prática cultural de cuidar do corpo. Mas, de um modo geral, quando observamos crianças negras trançadas, notamos duas coisas: a variedade de tipos de tranças e o uso de adereços coloridos. Tal prática explicita a existência de um estilo negro de pentear-se e adornar-se, o qual é muito diferente das crianças brancas, mesmo que estas se apresentem enfeitadas. Essas situações ilustram a estreita relação entre o negro, o cabelo e a identidade negra. A identidade negra compreende um complexo sistema estético.

Depois de adultas, muitas mulheres negras reconciliam-se com as tranças. Agora, porém, elas apresentam-se estilizadas, desde as chamadas tranças africanas ou agarradinhas, que formam desenhos engenhosos no couro cabeludo, até as jamaicanas, de diferentes comprimentos. Esses penteados são também usados pelos homens, porém com menor freqüência.

Mesmo que reconheçamos que a manipulação do cabelo seja uma técnica corporal e um comportamento social presente nas mais diversas culturas, para o negro, e mais especificamente para o negro brasilei- ro, esse processo não se dá sem conflitos. Estes embates podem expressar sentimentos de rejeição, aceitação, ressignificação e, até mesmo, de negação ao pertencimento étnico/racial. As múltiplas representações construídas sobre o cabelo do negro no contexto de uma sociedade racista influenciam o comportamento individual. Existem, em nossa sociedade, espaços sociais nos quais o negro transita desde criança, em que tais representações reforçam estereótipos e intensificam as experiências do negro com o seu cabelo e o seu corpo. Um deles é a escola.

- Uma vez... tenho muito cabelo, mas antes eu tinha mais... e sempre assim, até uns sete anos pra nove anos, eu não tinha problema com cabelo, porque minhas tias, como eu te falei, mexiam com cabelo. Então, cada dia eu ia arrumadinha para o colégio. Tinha vez que minha tia alisava o meu cabelo, quando eu alisava não cortava mais, aí ele ficava grande! Minha tia alisava o meu cabelo, tinha dia que eu ia de trancinha, assim, agarradinha. Tinha vez que ela fazia as trancinhas acima, assim. Meu cabelo era grande, aí as trancinhas ficavam lindas, colocava bolinha. A gente enchia de bolinha assim, miçanguinha. Eu colocava, ficava balançando, todo mundo achava lindo. Eu era sempre baixinha, sempre miudinha. [...] Do grupo inteiro, todo mundo até hoje tem retrato meu lá no grupo que eles guardam. E não tinha problema não, sabe? Eles me chamavam de neguinha, às vezes os meninos mexiam comigo, mas eu não ligava, não. Eu não ligava, eu gostava do jeito que eu era. Eu fui... me acostumei comigo, me acostumei com o que eu era, com minha raça. Então, me acostumei e não ligava, não, mas o pessoal mexia. Isso aí eu tirava de... ao pé da letra. Não me atrapalhava, não. Eu gostava mesmo. Então, minha tia, quando arrumava o meu cabelo, nossa, eu ficava toda metida. Cada dia um penteado, nossa, eu achava o máximo, principalmente porque chamava muita atenção. As pessoas achavam lindo o penteado... (J., 23 anos, cabeleireira)

- Bom, a minha mãe, ela sempre cuidou, quando ela cuidava do meu cabelo, ela usava muita trancinha... então colocava aquele tanto de badulaque e tal. Aí os meninos ficavam assim... olhando, olhava porque colocava aquilo $e$ tal. Mas apelido, essas coisas, não, até que muita gente co- 
meçou a aderir também. Tinha muita menininha da minha idade e tal, também que as mães colocavam tranças. Até porque os professores pediam pra evitar piolho, né, esse tipo de coisa, então, eu num... eu nunca tive problema, não. Nunca tive, graças a Deus! (AD., 25 anos, auxiliar de escritório)

- Na infância eu me senti assim, uma verdadeira japonesa negra, né?... Minha mãe apertava tanto a minha trancinha, pra ir pra aula eu usava trancinha. Sabe aquelas trancinhas que faz tipo gominho, emendando uma na outra? Então eu sofria, apertava demais, eu sofria muito. (N.U., 26 anos, cabeleireira)

Se antes a aparência da criança negra, com sua cabeleira crespa, solta e despenteada, era algo comum entre a vizinhança e coleguinhas negros, com a entrada para a escola essa situação muda. A escola impõe padrões de currículo, de conhecimento, de comportamentos e também de estética. Para estar dentro da escola é preciso apresentar-se fisicamente dentro de um padrão, uniformizar-se. A exigência de cuidar da aparência é reiterada, e os argumentos para tal nem sempre apresentam um conteúdo racial explícito. Muitas vezes esse conteúdo é mascarado pelo apelo às normas e aos preceitos higienistas. Existe, no interior do espaço escolar, uma determinada representação do que é ser negro, presente nos livros didáticos, nos discursos, nas relações pedagógicas, nos cartazes afixados nos murais da escola, nas relações professor/a e aluno/a e dos alunos/as entre si. Estudos como o de Gonçalves (1985) apontam para que na maioria das vezes a questão racial existe na escola por meio da sua ausência e do seu silenciamento.

Na escola também se encontra a exigência de "arrumar o cabelo", o que não é novidade para a família negra. Mas essa exigência, muitas vezes, chega até essa família com um sentido muito diferente daquele atribuído pelas mães ao cuidarem dos seus filhos e filhas. Em alguns momentos, o cuidado dessas mães não consegue evitar que, mesmo apresentando-se bem penteada e arrumada, a criança negra deixe de ser alvo das piadas e apelidos pejorativos no ambiente escolar. Alguns se referem ao cabelo como: "ninho de guacho", "cabelo de bombril", "nega do cabelo duro", "cabelo de picumã"! Apelidos que expressam que o tipo de cabelo do negro é visto como símbolo de inferioridade, sempre associado à artificialidade (esponja de bombril) ou com elementos da natureza (ninho de passarinhos, teia de aranha enegrecida pela fuligem).

Esses apelidos recebidos na escola marcam a história de vida dos negros. São, talvez, as primeiras experiências públicas de rejeição do corpo vividas na infância e adolescência. A escola representa uma abertura para a vida social mais ampla, em que o contato é muito diferente daquele estabelecido na família, na vizinhança e no círculo de amigos mais íntimos. Uma coisa é nascer criança negra, ter cabelo crespo e viver dentro da comunidade negra; outra coisa é ser criança negra, ter cabelo crespo e estar entre brancos.

A experiência da relação identidade/alteridade coloca-se com maior intensidade nesse contato família/escola. Para muitos negros, essa é uma das primeiras situações de contato interétnico. É de onde emergem as diferenças e se torna possível pensar um "nós" - criança e família negra - em oposição aos "outros" - colegas e professores/as brancos. Embora o discurso que condiciona a discriminação do negro à sua localização na classe social ainda seja predominante na escola, as práticas cotidianas mostram para a criança e para o adolescente negro que o status social não é determinado somente pelo emprego, renda e grau de escolaridade, mas também pela posição da pessoa na classificação racial.

Pertencer ou não a um segmento étnico/racial faz muita diferença nas relações estabelecidas entre os sujeitos da escola, nos momentos de avaliação, nas expectativas construídas em torno do desempenho escolar e na maneira como as diferenças são tratadas. Embora atualmente os currículos oficiais aos poucos incorporem leituras críticas sobre a situação do negro, e alguns docentes se empenhem no trabalho com a questão racial no ambiente escolar, o cabelo e os demais sinais diacríticos ainda são usados como critério para discriminar negros, brancos e mestiços. A questão da expressão estética negra ainda não é considerada um tema a ser discutido pela pedagogia brasileira. 
Os sinais diacríticos operam como demarcadores da diferença. Quanto mais aumentam as vivências da criança negra fora do universo familiar, quanto mais essa criança ou adolescente insere-se em círculos sociais mais amplos, como é o caso da escola, mais manifesta-se a tensão vivida pelos negros na relação estabelecida entre a esfera privada (vida familiar) e a pública (relações sociais mais amplas).

São nesses espaços que as oportunidades de comparação, a presença de outros padrões estéticos, estilos de vida e práticas culturais ganham destaque no cotidiano da criança e do/a adolescente negros, muitas vezes de maneira contrária àquela aprendida na família. Em alguns casos, é o cuidado da mãe, a maneira como a criança é vista no meio familiar, que lhe possibilitam a construção de uma auto-representação positiva sobre o ser negro/a e a elaboração de alternativas particulares para lidar com o cabelo crespo. Diante disso, podemos inferir que saber lidar, manusear e tratar do cabelo crespo está intimamente associado a estratégias individuais de construção da identidade negra.

- Pra minha felicidade, a minha relação pessoa, mulher e o meu cabelo crespo foi ótima pelo fato de ter tido a minha mãe, que é uma cabeleireira conceituada aí já no mercado afro, que cuidou sempre do meu cabelo, eu nunca sofri. E ela tentou fazer com que eu nunca passasse em situações que ela passou com o cabelo crespo, com a dificuldade que ela teve com o cabelo dela. Então, assim, eu nunca tive problemas com alisamento, a vida inteira alisei o cabelo. Nunca tive aqueles problemas famosos com queimaduras e tudo mais. Sempre tive o meu cabelo saudável.

(F.A., 26 anos, cabeleireira)

A reação de cada pessoa negra diante do preconceito é muito particular. Essa particularidade está intimamente ligada à construção da identidade negra e às possibilidades de socialização e de informação. Como nos disse uma depoente, muitas vezes as pessoas são preconceituosas por causa da desinformação. Elas precisam ser reeducadas:

- Tenho amadurecimento pra isso. Então, essa questão da história do cabelo é muito em função disso. Minha irmã, ela trabalhava na Usiminas, então ela tinha mais contatos... não muito com negros, mas com pessoas que tinham outra visão, que davam outro tipo de incentivo. E eu custei a cair, vamos dizer assim, não vou chamar de mundo real, não, mas a encontrar essa história do negro pra me identificar legal. Acho que por isso que foi esse processo... lento! Não sei... foi esse processo passo a passo. E eu estou aqui: cabelo maravilhoso! Que eu amo... e eu ainda achei interessante que... quando eu solto ele assim todo mundo fica escandalizado. [risos] Aí um dia eu fui na padaria e a menina olhou pro meu cabelo: "Por que cê num corta seu cabelo?" [risos] Eu achei tão fantástico! "Por que cê num corta seu cabelo?" Eu falei assim: "Porque eu gosto dele assim”, de uma forma muito tranqüila... E eu achei legal que ela virou e falou assim: "Deve dar muito trabalho!" $\mathrm{Na}$ visão dela, para eu colocar o meu coque assim, simplesmente amarrar... Aí, ninguém entende esse coque no meu cabelo e todo mundo fica... principalmente os brancos, que não sabem como que é o simples amarrado. Todo mundo quer pegar e ver. "Como é que seu cabelo fica assim, pra cima?" Entendeu? Então, o porquê... porque nós sabemos como que ele fica pra cima, mas as pessoas que olham... Gente!... são inúmeras as pessoas... Às vezes a cabeleireira B. até me chama a atenção por causa disso, que as pessoas querem pegar, ver. É diferente. "Como é que cê faz pro seu cabelo ficar armado dessa forma?" Então eu explico que o meu cabelo é crespo, que ele não é liso, por isso que ele fica pra cima, se eu alisasse com certeza ele cairia. E eu amarro... Aí que as pessoas: “Ah, então ele tá amarrado, né?” Na cabeça das pessoas, eu acho que elas não conseguem ver que eu jogo esse cabelo todo pra cima e amarro. E aí eu achei interessante... e aí ela comentou: “Ah, não, isso assim dá muito trabalho.” Aí eu expliquei pra ela que não dava trabalho... aí eu mostrei pra ela: "Olha, tá vendo, ele tá amarrado. É só eu pentear...” Ainda olhei pra ela e falei assim: “Tem como pentear!!! Eu penteio meu cabelo... e amarro". $\mathrm{E}$ ao invés de amarrar ele pra baixo como as pessoas têm o costume de amarrar, amarro ele pra cima. Tá diferente, é só você perguntar! [gargalhadas] Mas é claro, fico bem tranqüila, porque eu acho legal as pessoas terem essa liberdade de questionar. Porque se de repente entro numa de... porque meu cabelo é assim, eu quero é assim, pronto e acabou e você não tem nada com isso... A pessoa nem sabe como éo processo de um cabelo... do negro... E aí a gente vai infor- 
mando de uma forma tranqüila... porque é uma informação. (D., 38 anos, contabilista)

Embora existam aspectos comuns que remetem à construção da identidade negra no Brasil, cada vez mais entende-se que, para discuti-la, precisamos sempre considerar como os sujeitos a constroem, não somente no nível coletivo, mas também no individual. $\mathrm{O}$ mais difícil é, após conhecer essas estratégias individuais, interpretá-las, não julgá-las e nem classificá-las como mais ou menos politizadas, mais ou menos corretas. Quem sabe, assim, compreenderemos como o negro constrói a sua identidade nos seus próprios termos.

Há, então, um campo mais íntimo que se refere à esfera da subjetividade, que nem mesmo a intervenção familiar e um debate crítico produzido no espaço da militância ou da escola conseguem alcançá-lo na sua totalidade. Isso não significa ignorar o peso da história, da sociedade e da cultura, mas destacar que a subjetividade também tem a sua importância no processo do tornar-se negro. A relação do negro com o cabelo nos aproxima dessa esfera mais íntima.

É nesse sentido que o olhar sobre a adolescência dos sujeitos negros se faz importante. A adolescência é um dos momentos fortes na construção da subjetividade negra. Alguns/mas depoentes, ao falarem sobre a sua relação com o cabelo, relembraram as experiências vividas nesse ciclo da vida e falaram da sensação de "desencontro", de mal-estar e de desconforto em relação ao seu tipo físico, seu cabelo, sua pele e sua cor, vivida na adolescência. Dependendo do sujeito e da sua forma de lidar com essa experiência, temos, hoje, um adulto que acumula certos traumas raciais ou que lida com desenvoltura diante dos seus dilemas étnicos e raciais.

Para o/a adolescente negro/a, a insatisfação com a imagem, com o padrão estético, com a textura do cabelo é mais do que uma experiência comum dos que vivem esse ciclo da vida. Essas experiências são acrescidas do aspecto racial, o qual tem na cor da pele e no cabelo os seus principais representantes. Tais sinais diacríticos assumem um lugar diferente e de destaque no processo identitário de negros e brancos brasileiros. A rejeição do cabelo pode levar a uma sensação de inferioridade e de baixa auto-estima contra a qual faz-se necessária a construção de outras estratégias, diferentes daquelas usadas durante a infância e aprendidas em família. Muitas vezes, essas experiências acontecem ao longo da trajetória escolar. A escola pode atuar tanto na reprodução de estereótipos sobre o negro, o corpo e o cabelo, quanto na superação dos mesmos.

- E eu cresci assim, é... é... constrangida, porque na escola eu fui barrada também... Teve bailado e eu quis participar do bailado e diziam que não, que não podia, não. Que só iam as meninas brancas, as meninas bonitas.

Pesquisadora: E falaram isso com vocês claramente?

-Falaram, falaram, falaram, falaram... [pausa] Eu custei, eu sofri muito, muito, muito a entender que negro era gente também... Eu vim descobrir que negro tinha história quando fui pro colégio, porque até então, pra mim negro era um bicho, era um... uma... um defeito, sabe? E morria de vontade de ser branca, por causa do cabelo, pra freqüentar assim essas coisas... pra aproveitar.

Pesquisadora: Isso te lembra alguma coisa? Você sente? Por que essa ênfase tão grande no nosso cabelo?

- Porque, assim... o branco tem o cabelo liso, né? Então, o negro tem o cabelo já crespo, às vezes chega a ser carapinha mesmo. Mas vem daí a influência do branco sobre o negro, eu acho que quando você não tem noção do que é ser negro, você se cobra muito aquele cabelo maravilhoso, né, aquela coisa bonita de passar a mão, de cair, de “Ai, o meu cabelo é lindo, maravilhoso!" Quando a gente tem uma noção do que é ser realmente negro, aí a gente se aceita com o cabelo que a gente tem. Eu, por exemplo, eu daria tudo pra ter o meu cabelo anelado, sabe, eu daria tudo para ter o meu cabelo anelado. Mas não consigo tê-lo crespo. Num sei te explicar por que, mas não consigo... Talvez seja, nem seja por mim mesma, seja pela cobrança... cê chega num lugar pra trabalhar, se você... eles olham. Você chega num lugar pra se divertir... às vezes cê tá passando na rua, aí um grita de lá: "Vamos pentear o cabelo"? Ou então cantam aquela musiquinha assim: "Nega do ca- 
belo duro, qual é o pente que te penteia”. Quer dizer, é muita coisinha, é, é.... muita ironia mesmo, às vezes, das pessoas... É muito complicado, muito complexo, né? (F., 36 anos, professora)

Outras mulheres negras e clientes dos salões pesquisados, quando perguntadas sobre a importância que o cabelo passou a ter depois de sua infância e adolescência, assim se pronunciaram:

-É porque aí você já assumiu uma identidade diferente, você já entra no caso da aparência, quer competir com as pessoas, no mesmo ponto de vista. Então, se você vai a uma festa, ou mesmo no dia-a-dia, você quer ter uma aparência melhor, você vai se cuidar. Na época eu já deixei os meus cachos, já parti pra um alisamento, já parti pra um bobe no cabelo, e aquilo se identificava comigo, pra mim assumiu uma aparência de competição com as outras pessoas, se fulano fazia assim eu não queria fazer igual, mas eu queria ficar de maneira comparativa: ela na dela e eu na minha. Como minhas colegas: umas usavam seu rabo de cavalo, seus penteados da época pigmaleão, touca holandesa, essas coisas; então, eu procurava ir atrás disso dentro daquilo que meu cabelo permitia. (S.G, 60 anos, aposentada)

- Aí, depois que eu comecei a ficar mocinha, esse período é que foi difícil. Que aí é que eu tinha que trabalhar, não tinha ninguém pra arrumar o meu cabelo mais. Tinha uma época que eu não queria nem saber, nem cuidar de cabelo. Ele ficava todo espetadinho pra cima. Era muito cabelo, era difícil de arrumar. Então eu amarrava ele pra cima, assim, ficava aquela bucha, sabe? Eu não ligava, não estava nem aí também não, era meio desligada mesmo. Tinha vez também que... igual na época dos doze, treze, eu gostava muito de brincar de casinha, já tinha esse trem de Salão também. Eu colocava aqueles... pegava blusas e colocava assim na cabeça e ficava na frente do espelho e falava que era meu cabelo. Me lembro que pegava as toalhas da minha tia e colocava na cabeça” [risos]. (J., 23 anos, cabeleireira)

- Na adolescência era uma tragédia! Porque a testa era marcada de dentinho de pente, de ferro quente. Aquele cabelo é... aquele cheiro de gordura. Porque hoje em dia, tem as coisas assim, aperfeiçoou, e tem o creme certo pra passar. Antigamente, não, a gente assentava no fogão e vinha aquela coisa na cabeça cheia de fumaça, a gente queimava tudo. É babyliss que eu usava também. Era um trauma, janela do ônibus, jamais pedia para abrir. Nossa, pelo amor... aquele calor com as janelas... porque meu cabelo vai espetar. Quando eu ia na danceteria, aquelas colegas tudo com cabelo lindo. Ia no banheiro, aquele calor, molhava o cabelo. Eu jamais podia... uma que não precisava, que já estava todo escorrido de... de... aquela fumaça que tinha na danceteria, já caía tudo, então não tinha como, mesmo...É... clube, não podia jamais, porque... nossa, como é que ia molhar o cabelo? Nossa! Não gosto, tenho pavor de água, não sei nadar... Porque, é lógico, como que ia molhar o cabelo, não tinha como [risos]. [...] e na época, tipo assim, umas... eu tinha mais ou menos uns 17 anos, eи conheci um rapaz. Eu achei ele uma gracinha e tal. Nessa época eu já usava... aí já passou o tempo do cabelo alisado, usava trancinha africana. E eu colocava um aplique. E estava assim o nosso namoro, tinha uns dois meses... ele adorava minha trança, aí teve um dia, que ele falou assim: "Nossa! É tão lindo o seu cabelo, solta o seu cabelo”... [risos]. Eu falava: "Pra que você quer que eu solto o meu cabelo?” Ele falava assim: “Não, solta o seu cabelo". Ah! Ele nem imaginava que era aplique, porque era tão bem feito. Cabelo idêntico ao meu e tal. Eu falei: "Não, não vou soltar meu cabelo, não". Só que a gente ia num pagode e tinha umas meninas que usavam trancinha. Aí não sei o que aconteceu, alguém falou com ele que era aplique. Que deve ter falado: “Ah! Aquele cabelo dela é falso!” Um dia ele falou assim: “Eu sei por que...”. Ele falou: “Solta o seu cabelo... Eu sei porque você nunca vai soltar o seu cabelo, não é?” Eu disse: "Ih! Alexandre, pelo amor de Deus, vamos mudar de assunto?” Ele disse assim: “Ah! Eu sei por que você não vai soltar o seu cabelo, sua amiga me falou que você usa peruca, que você é careca, não é?” Nossa! Foi uma tragédia! Eu tomei pavor mortal, tomei um ódio mortal dele. Ele falou assim, passando a mão assim no meu rosto: "Eu sei, tudo bem. É porque você não tem cabelo, você é careca, você usa peruca" [risos]. (N.U., 26 anos, cabeleireira)

A manipulação do próprio cabelo e a visão do outro sobre o cabelo do negro assumem contornos 
diferentes, de acordo com o gênero e a geração. Deslindar os impactos desse processo sobre os sujeitos implica compreender as práticas culturais, o processo histórico e a construção do racismo no Brasil. Contudo, há uma implicação mais profunda e desafiadora sobre a qual nos falam os depoimentos acima: entender a construção da questão racial na subjetividade e no cotidiano dos indivíduos, e o peso da educação escolar nesse processo.

Quando conversamos com os/as entrevistados/as sobre a sua opinião, hoje, a respeito da relação do negro com o cabelo, deparamos-nos com momentos tensos, discursos ambíguos e respostas confusas. A pergunta remetia também ao lugar do negro na esfera da subjetividade, e não somente ao sujeito político e cultural. Nesse momento, homens e mulheres negras eram convidados a falar de si, a partir de seu interior, da sua própria pele. É possível que essa ebulição de sentimentos e emoções tenha trazido à tona, ao âmbito da consciência, aquilo que está submerso na esfera do inconsciente e, por isso mesmo, não é tão fácil de ser dito. A nosso ver, essa situação apresenta algo mais complexo: a construção da identidade negra no Brasil passa pelo que Mauss (1974), ao estudar as técnicas corporais, chamou de fatores fisio-psico-sociológicos.

Essa maneira particular de relacionar-se com o corpo, com a subjetividade e à cultura dá-se em um determinado contexto social, histórico e político. E é esse contexto, juntamente com a experiência individual, que vai compor o complexo terreno da identidade negra. Homens e mulheres negras de diversas partes do mundo constroem-na de formas variadas, embora tragam consigo algo que os une: um pertencimento racial, oriundo de uma mesma ancestralidade africana, cuja maneira de lidar com o cabelo é uma forte expressão da cultura.

Esse ponto comum, que atravessa a história dos negros, remete a uma questão que se apresenta cotidianamente na sociedade e no universo escolar: nas sociedades em que a questão racial é um dos aspectos estruturantes das relações sociais de poder, o cabelo e a cor da pele, sendo os sinais mais visíveis da diferença racial e possuidores de uma forte dimensão sim- bólica, são vistos como símbolos de inferioridade (Kobena, 1994, p. 4). O racismo, sendo um código ideológico que toma atributos biológicos como valores e significados sociais, impõe ao negro uma série de conotações negativas que o afetam social e subjetivamente. No entanto, no movimento dialético das relações sociais, a ação do racismo sobre os negros resulta em formas variadas, sutis e explícitas de reação e resistência. Nesse contexto, o cabelo e a cor da pele podem sair do lugar da inferioridade e ocupar o lugar da beleza negra, assumindo uma significação política. Esse é mais um dos motivos pelos quais consideramos que a escola deve superar os preconceitos em relação à estética negra.

Mas, para além de tanta particularidade, quais seriam os significados universais da relação do homem e da mulher com o cabelo? Segundo Queiroz (2000, p. 28), o estado dos cabelos pode revelar a trajetória de vida de uma pessoa, sua condição de existência e o momento vivido no interior de um determinado grupo social. $\mathrm{O}$ autor chama a atenção para o fato de que é comum cortar ou raspar os cabelos por ocasião dos ritos de passagem, o que também é comum entre nós quando do ingresso na universidade, em prisões, em instituições militares ou religiosas. Há, também, uma relação entre cabelo, poder e potência sexual. Por isso, cortá-lo ou raspá-lo pode equivaler, simbolicamente, à castração. Essa é a condição dos novatos, dos recém-admitidos em determinadas instituições. No entanto, os cabelos rebeldes, soltos e descuidados podem expressar independência ou mesmo relutância às normas sociais, como é o caso de líderes religiosos, profetas, rastafaris. É muito comum encontrarmos entre os/as docentes a presença de relatos que associam os cabelos rastafaris e a estética dos integrantes do movimento hip-hop à sujeira e à marginalidade. No ambiente escolar, essas associações, muitas vezes, extrapolam a esfera individual e transformam-se em representações coletivas negativas sobre o negro, seu cabelo e sua estética.

Dessa forma, consideramos importante para nós, do campo da educação, compreender que, para além do significado social mais amplo e mais genérico do 
cabelo, existem variações de acordo com a cultura, classe, raça, idade, sexo, nacionalidade, contexto histórico e político. Cortar o cabelo, alisá-lo, raspá-lo, mudá-lo pode significar não só uma mudança de estado dentro de um grupo, mas também a maneira como as pessoas se vêem e são vistas pelo outro; o cabelo compõe um estilo político, de moda e de vida. Em suma, o cabelo é um veículo capaz de transmitir diferentes mensagens, por isso possibilita as mais diferentes leituras e interpretações. Desse modo, para muitos, o cabelo é a moldura do rosto e um dos primeiros sinais a serem observados no corpo humano.

Circulando pelo salão, fui até a sala da manicure, onde I. fazia a unha de S., uma vendedora de tecidos. S. é negra, tem o cabelo cortado bem curto, estilo máquina 1 . Ao conversarmos, ela me disse que resolveu cortar o cabelo bem curto porque ele dava muito trabalho. Quando acordava, o marido ficava brincando com ela, chamando-a de "Os Simpsons". Ela disse que quando cortou o cabelo sentiu-se mais bonita e que até vendeu melhor os seus produtos. Ela disse: "O cabelo é a moldura do rosto! A gente pode estar com uma roupa linda, mas se o cabelo não estiver bonito, não dá." Essa é uma opinião comum a todas as pessoas que encontro no salão. (Diário de campo, 16/10/1999)

Chegou uma senhora negra com a filha e o neto. Ela assentou perto de mim quando eu estava no banho infravermelho, e conversou sobre o cabelo, o que é comum no salão. Falou-me de como o seu cabelo era maltratado, de como ele caiu, e que quando chegou no Salão D. ela estava quase sem cabelo. "Agora é que ele está melhor!”, disse ela, toda satisfeita. E continuou: "Porque você sabe, minha filha, quando a gente vai sair, a gente vê só o cabelo." "A senhora acha mesmo?", perguntei-lhe. "Mas é claro!!!”, respondeu-me enfaticamente. (Diário de campo, $12 / 05 / 2000)$

$$
* * *
$$

Consideramos, então, que o estudo sobre as representações do corpo negro no cotidiano escolar poderá ser uma contribuição não só para o desvelamento do preconceito e da discriminação racial na escola, como também poderá ajudar-nos a construir estratégias pedagógicas alternativas que nos possibilitem compreender a importância do corpo na construção da identidade negra de alunos/as, professores/as negros, mestiços e brancos, e como esses fatores interferem nas relações estabelecidas entre esses diferentes sujeitos no ambiente escolar. Na escola, não só aprendemos a reproduzir as representações negativas sobre o cabelo crespo e o corpo negro; podemos também aprender a superá-las. Para isso, elas terão que ser consideradas temáticas merecedoras de um lugar em nosso currículo e em nossas discussões pedagógicas. Mas quais serão as representações sobre a relação negro, corpo e cabelo presentes na escola? Em que momentos elas aparecem e como elas aparecem? Como tais representações se manifestam no currículo? Como os sujeitos negros e brancos vivem suas experiências corpóreas dentro e fora da escola? Muitas vezes, esses processos delicados e tensos passam despercebidos pela instituição escolar e pelos/as profissionais da educação, e não são incluídos nos debates e nas discussões desenvolvidas nos cursos de formação de professores/as.

O estudo sobre o corpo e o cabelo, como ícones da identidade negra presentes nos processos educativos escolares e não escolares, poderá apontar-nos outros caminhos além da denúncia da reprodução de preconceitos e estereótipos. A manipulação do cabelo do negro e da negra, nessa perspectiva, pode ser vista como continuidade de elementos culturais africanos ressignificados no Brasil. Parafraseando Munanga (2000, p. 99), quando este autor escreve a respeito da arte afro-brasileira, podemos dizer que descobrir a africanidade presente ou escondida na manipulação do cabelo do negro e da negra da atualidade, e nos penteados por eles realizados, constitui uma das preocupações primordiais para a definição da força histórica e cultural desse segmento étnico/racial. Esses são aspectos a serem considerados pela educação escolar.

NILMA LINO GOMES, doutora em antropologia social pela USP, é professora adjunta na Faculdade de Educação da Universidade Federal de Minas Gerais. Além de vários artigos e capítulos 
de livros, publicou A mulher negra que vi de perto: o processo de construção da identidade racial de professoras negras (Belo Horizonte: Mazza, 1995); e organizou, em colaboração com Lilia K. M. Schwartz, Antropologia e história; debate em região de fronteira (Belo Horizonte: Autêntica, 2000), e com Petronilha Beatriz Gonçalves e Silva, Experiências étnico-culturais para a formação de professores (Belo Horizonte: Autêntica, 2002). Atualmente, junto com o professor Juarez T. Dayrell, desenvolve o projeto de pesquisa Juventude, práticas culturais e identidade negra. E-mail: nilmagomes@uol.com.br

\section{Referências bibliográficas}

ARROYO, Miguel G., (2000). Ofício de mestre. Petrópolis: Vozes. BRUNER, Jerome, (2001). A cultura da educação. Porto Alegre: Artmed.

GOMES, Nilma Lino, (2002). Corpo e cabelo como ícones de construção da beleza e da identidade negra nos salões étnicos de Belo Horizonte. Tese de Doutorado. Faculdade de Filosofia, Letras e Ciências Humanas, USP.

GONÇALVES, Luiz Alberto Oliveira, (1985). O silêncio: um ritual pedagógico a favor da discriminação racial. Dissertação de mestrado. Faculdade de Educação, Universidade Federal de Minas Gerais.
KOBENA, Mercer, (1994). Black hair: style politics. In: Welcome to the jungle: new positions in Black cultural studies. New York: Routledge. p. 97-128.

MARTINS, José de Souza, (1999). A dialética do corpo no imaginário popular. Sexta-feira, antropologia, artes, humanidades. São Paulo, Editora Pletora, n. 4, p. 46-54.

MAUSS, Marcel, (1974). As técnicas corporais. In: Sociologia e antropologia. São Paulo: EPU. p. 209-233.

MUNANGA, Kabengele, (2000). Arte afro-brasileira: o que é, afinal? In: Associação 500 anos Brasil artes visuais. Mostra do redescobrimento. Arte afro-brasileira. São Paulo: Fundação Bienal de São Paulo. p. 98-111.

QUEIROZ, Renato da Silva, (org.) (2000). O corpo do brasileiro: estudos de estética e beleza. São Paulo: SENAC.

QUEIROZ, Renato da Silva, OTTA, Emma, (2000). A beleza em foco: condicionantes culturais e psicológicos na definição da estética corporal. In: QUEIROZ, Renato da Silva, (org.). $O$ corpo do brasileiro: estudos de estética e beleza. São Paulo: SENAC. p. 13-66.

RODRIGUES, José Carlos, (1986). O tabu do corpo. Rio de Janeiro: Dois Pontos.

Recebido em agosto de 2002 Aprovado em outubro de 2002 
mechanisms operate to govern childhood. This research, inspired by Michel Foucault's ideas, seeks to show how mechanisms of power/knowledge concerning childhood are produced within pedagogical relationships. In this article, an analysis of the "government" of childhood is undertaken, examining propositions presented in the document and stressing the ways technologies of the self operate. Related to political technologies and governmental rationalities this work emphasises the $R C N$ as a mechanism that proposes to produce children's subjectivities and that aims to organise, impart and control the circulation of knowledge in early childhood institutions.

Key-words: early childhood education, children's subjectivities, technologies of the self, power mechanisms.

Nilma Lino Gomes

Trajetórias escolares, corpo negro e cabelo crespo: reprodução de estereótipos e/ou ressignificação cultural?

O trabalho estabelece uma articulação entre os processos educativos escolares e não-escolares e a construção da identidade negra. Discutem-se as representações e as concepções semelhantes, diferentes e complementares sobre o corpo negro e o cabelo crespo, construídas dentro e fora do ambiente escolar, a partir de lembranças de adolescentes e jovens negras entrevistadas durante a realização de uma pesquisa etnográfica sobre corpo e cabelo como ícones identitários em salões étnicos. Pretende-se compreender o significado social do cabelo e do corpo e os sentidos a eles atribuídos pela escola e pelos sujeitos negros entrevistados. $\mathrm{O}$ entendimento desse contexto revela que o corpo como suporte de construção da identidade ainda não tem sido uma temática privile- giada nos estudos sobre relações raciais e educação.

Palavras-chave: educação, identidade negra, corpo.

School trajectories, black skin and

Afro hair: reproduction of

stereotypes and/or cultural resignificance

This study establishes an articulation between school and non-school educational processes and the construction of Negro identity. It discusses the representations and similar, different and complementary conceptions about the Negro body and afro hair, constructed within and without the school environment, based on the memories of adolescent and young Negros interviewed during an ethnographic research on body and hair as identity icons in ethnic hairdressing salons. The intention is to understand the social significance of hair and body and the meanings attributed to them by the school and by the Negro subjects interviewed. The understanding of this context reveals that the body as a support for the construction of identity has not been a theme given prominence in studies on racial relations and education.

Key-words: education, negro identity, body.

Maria Helena Rodrigues Paes A questão da língua na escola indígena em aldeias Paresi de Tangará da Serra-MT

Os índios Paresi, de Tangará da Serra-MT, embora de grande apego aos elementos da sua cultura tradicional, vivem um processo de intensas relações com a sociedade envolvente, ressignificando seus hábitos tradicionais e os incorporados da cultura ocidentalizada, sendo a escolarização formal um instrumento essencial para transmissão dos códigos simbólicos da cultura ocidentalizada. Em um mo- mento de transição entre um modelo de escola tradicional para um modelo que atenda às especificidades da realidade local, este trabalho propõe uma reflexão, à luz dos estudos culturais, do discurso da valorização da língua portuguesa na rotina escolar, não entendendo esta opção como sobreposição aos valores da cultura tradicional, num processo de homogeneização, mas como uma ferramenta e um instrumento de poder, que visa marcar o lugar do Paresi na sociedade envolvente.

Palavras-chave: educação indígena, hibridização, linguagem.

The language question in the present dilemmas of the indigenous school in paresi villages in Tangará da Serra in the State of Mato Grosso

The Paresi Indians, from Tangará da Serra, in the State of Mato Grosso, although greatly attached to elements of their cultural tradition, experience a process of intense relations with the society by which they are surrounded, giving new meaning to their traditions and to those incorporated from the westernised culture. In this process, formal schooling has proved an essential instrument for the transmission of symbolic codes of westernised culture. In a phase of transition from a traditional school model to a model which attends the specificities of local reality, this paper proposes a reflection, in the light of cultural studies, on the discourse which values the use of Portuguese language in school routine, not understanding this option as an imposition on the values of the traditional culture as part of a process of homogenisation but as a tool and powerful instrument which aims to establish the place of the Paresi in the surrounding society.

Key-words: indigenous education, hybridisation, language. 